\title{
VIRUS DISEASES IN PREGNANCY AND CONGENITAL DEFECTS
}

\author{
BY \begin{abstract}
Statistical Research Unit of the Medical Research Council, London School of Hygiene and Tropical Medicine
\end{abstract} \\ A. BRADFORD HILL, RICHARD DOLL, T. McL. GALLOWAY, AND J. P. W. HUGHES
}

To determine the probability that an illness of the mother during her pregnancy will give rise to a congenital malformation in the infant, essentially demands a prospective method of inquiry. In other words, the attack of illness in the pregnant woman must first be observed and medically diagnosed, and the condition of the child born to her must subsequently be noted. The retrospective approach, i.e. noting first the congenital deformity in the new-born child and then obtaining the history of the mother during pregnancy, inevitably omits the normal children whose mothers were affected, and is thus bound to give a highly exaggerated picture of the risks involved. The prospective inquiry is, however, extremely difficult to carry out on an adequate scale. The attack rates from infectious diseases are relatively low in adult life and very large numbers of women must be observed. It is specially important, too, that the occurrence of disease in the mother be recognized and recorded at a time when she may not even know that she is pregnant, i.e. during the first month of pregnancy.

One way of securing such records in Great Britain has been described in an earlier paper (Bradford Hill and Galloway, 1949). The data there used were automatically collected by the approved societies operating up to July 5,1948 , under the National Health Insurance Acts. Under these Acts, if an employed and insured married woman drew benefit for a sickness which caused her to be absent from work, she had to present a sickness certificate giving the dates of her illness and the general practitioner's diagnosis of its cause. If she subsequently gave birth to a child (live or still) she would be entitled to draw maternity benefit and the date of birth would therefore also be recorded by the approved society. Thus the dates of the two events would be available in records automatically maintained. By these means information was collected on 22 cases over the space of some 2 years; they included ten cases of rubella and six of measles. The infants were specially examined not long after birth and one case of congenital heart disease following rubella in the first month of pregnancy was observed. The authors concluded their report with the hope that it might "be possible to extend these observations through the records of the new health and social services" (which came into being on July 5,1948 ). This hope has been fulfilled. With the aid of the Ministry of Pensions and National Insurance we have been able to collect similar records for 100 women reported to have suffered from rubella, measles, mumps, or chicken pox during, or shortly before, pregnancy. A further seven cases were brought to our notice privately but prospectively (i.e. before the birth of the child). It is with this total of 129 "doubleevents" that the present paper is concerned.

\section{Notification OF CASES}

The identification of relevant cases followed the system described above. In local offices of the Ministry of Pensions and National Insurance a special note was made on the file of any married woman who returned a sickness certificate signed, as required, by a medical practitioner and bearing a diagnosis of rubella (German measles), morbilli (measles), varicella (chicken pox), or epidemic parotitis (mumps). A form was set up showing the identification particulars of the insured woman and the nature and dates of her illness. If the same woman claimed maternity benefit for the birth of a child within 12 months of the end-date of that illness, then the date of confinement and the name of the doctor or midwife in attendance were added to the form, and notification of the "double event" was made to the Ministry.

In setting up this notification system, steps were specially taken to avoid any breach of medical 
confidence. As each case was notified to the Ministry of Pensions and National Insurance a letter from the Chief Medical Officer to the Ministry (or his deputy) was sent to the doctor who had signed the original sickness certificate. This letter enclosed a copy of the completed form relating to his patient and told him that the case was of interest in an inquiry into congenital defects being made by one of us (B. H.) from whom he would be hearing. At the same time the Ministry sent to the Statistical Research Unit similar particulars of the case-dates of illness, etc.- and including the certifying doctor's name but omitting that of the patient.

On receipt of these particulars we immediately communicated with the doctor asking for his help and for permission to visit the mother and baby, known by name to him but not to us. Very few difficulties arose and the mothers were seen and the babies examined by one of us in nearly all instances.

The scheme was operated in London and the home counties from November, 1949, and in a group of midland and north-midland counties* from January, 1951, until the end of March, 1953.

It will be noted that the method of inquiry is limited to the observation of stillbirths and to the condition of liveborn infants; it automatically excludes miscarriages and abortions. If virus diseases in pregnancy contribute to early foetal loss this inquiry cannot reveal it.

\section{DATA}

In analysing the data we have calculated the stage of the pregnancy from the first day of the last preceding menstrual period. This is open to criticism in that the first 2 weeks of "pregnancy" may consequently represent a period which actually preceded conception. We have, however, followed this technique, because it is the normal obstetric procedure, which most other investigators have followed, and furthermore, because several instances have been recorded in which rubella manifested itself in the mother during the 2 weeks following the menstrual period and the infant showed the characteristic rubella defects. On the other hand, no instances have been recorded in which the infection appeared before the last menstrual period. In those cases which followed infection in the first 2 weeks, the infection may have persisted until after conception or the wrong date may have been given for the last menstrual period. In the present series, we determined the date of onset of the last menstrual

* Staffordshire, Warwickshire, Derbyshire, Leicestershire, Northamptonshire, and Nottinghamshire. period whenever possible according to the mother's statement. In 44 cases ( 37 per cent.), however, no such statement was recorded, and, in these, we calculated the date by subtracting 40 weeks from the date of delivery.

Our method of inquiry was based, for administrative convenience, upon a date of delivery that lay within 12 months of the end of the specified illness. It thus automatically produced a number of cases of disease that must have preceded conception by any time up to 3 months. It is, however, of interest to see whether there is any evidence of congenital defects related to an illness shortly preceding conception and we have, therefore, examined such babies and included them in the study.

Of the total 129 cases notified to us we subsequently omitted ten from the analysis. In four cases the diagnosis of the illness that occurred during pregnancy was not substantiated when we visited the mother and certifying practitioner (three cases of "measles" in the series reported by Bradford Hill and Galloway and one of "mumps" in the later series). Three cases of measles had occurred too long before conception to be of interest, and one of mumps occurred too close to delivery (4 days). These eight exclusions are obviously called for and are of no importance, but two other cases were lost for different reasons. In one case of chicken pox in the fourth week, the mother refused to allow the child to be examined and no report could be obtained from the family doctor. In one case of mumps in the 11th week, no early examination. of the infant was made and the case was subsequently lost to sight. $\dagger$

The remaining 119 cases are included in the analyses that follow. They concern 44 cases of rubella (6 preceding and 38 during pregnancy), 35 cases of mumps (6 preceding and 29 during pregnancy), 30 cases of chicken pox ( 6 preceding and 24 during pregnancy), and 10 cases of measles (4 preceding and 6 during pregnancy). One of the women who had chicken pox gave birth to twins so that altogether 120 babies were available for study of whom 110 were personally examined by one of us shortly after birth. In the remaining ten we had information from a hospital or private doctor. Further information was obtained after the child had reached at least 3 years of age. In most cases we again made personal contact, usually with a special examination, and in the remainder we had reports from private doctors, except in two cases in which the family had emigrated and we had to rely upon a report of normality from the mother.

†This child (birth weight $10 \mathrm{lb} .4 \mathrm{oz} ; 4 \cdot 7 \mathrm{~kg}$.) was traced after this paper had gone to press; at age $4 t$ years it had no physical defects. 


\section{RESULTS}

RUBELLA.-The observations on rubella are set out in Table I and in the following brief case histories:

(1) Start of last menstrual period (mother's statement) 13.4.52, (calculated date) 13.3.52; onset of rubella 24.4.52; delivery 18.12.52. Birth weight $4 \mathrm{lb}$. $9 \mathrm{oz}$. $(2 \cdot 1 \mathrm{~kg}$.). Bilateral cataract, harsh systolic murmur all over praecordium. Hospital report "murmur suggestive of ventricular septal defect". Died aged 3 months; certified cause congenital heart disease; no autopsy.

(2) Start of last menstrual period (mother's statement) 9.4.52, (calculated date) 8.4.52; onset of rubella 29.4.52; delivery 13.1.53. Birth weight $6 \mathrm{lb} .2 \mathrm{oz}$. $(2 \cdot 8 \mathrm{~kg}$.). Bilateral cataract, microphthalmos.

(3) Start of last menstrual period (calculated date) 19.2.47; onset of rubella 17.3.47; delivery 26.11.47. Birth weight $5 \mathrm{lb} .8 \mathrm{oz}$. (2.5 kg.). Patent interventricular septum, severe bilateral deafness. Deafness not detected at first examination (Hill and Galloway, Case 1).

(4) Start of last menstrual period (calculated date) 7.5.47; onset of rubella 13.6.47; delivery 11.2.48. Birth weight not known. Died aged 5 weeks; certified cause pneumonia. Not examined personally (Hill and Galloway, Case 2).

TABle I

OBSERVATIONS ON RUBELLA (GERMAN MEASLES)

\begin{tabular}{|c|c|c|c|c|c|}
\hline \multicolumn{2}{|c|}{$\begin{array}{l}\text { Stage at which } \\
\text { Rubella } \\
\text { Commenced }\end{array}$} & $\begin{array}{c}\text { No. } \\
\text { of } \\
\text { Cases }\end{array}$ & $\begin{array}{l}\text { No. of } \\
\text { Babies Still- } \\
\text { born or who } \\
\text { Died before } \\
\text { Examination }\end{array}$ & $\begin{array}{l}\text { No. of Live- } \\
\text { born Babies } \\
\text { in whom } \\
\text { Abnormali- } \\
\text { ties were } \\
\text { Detected }\end{array}$ & $\begin{array}{l}\text { No. of } \\
\text { Babies Born } \\
\text { weighing } \\
5 \frac{1}{2} \text { lb. or } \\
\text { Less }\end{array}$ \\
\hline \multicolumn{2}{|c|}{$\begin{array}{l}\text { Before last } \\
\text { menstrual period }\end{array}$} & 6 & 0 & 0 & 0 \\
\hline $\begin{array}{l}\text { Week of } \\
\text { Pregnancy }\end{array}$ & $\begin{array}{c}\text { 1st } \\
\text { 2nd } \\
\text { 3rd } \\
\text { 4th } \\
\text { 5th } \\
\text { 6th } \\
7 \text { th } \\
\text { 8th } \\
\text { 9th } \\
\text { 10th } \\
\text { 11th } \\
\text { 12th } \\
\text { 13th } \\
\text { 14th } \\
\text { 15th } \\
\text { 16th } \\
\text { 17th } \\
\text { 18th } \\
\text { 19th } \\
\text { 20th } \\
\text { 21st } \\
\text { 22nd } \\
\text { 23rd } \\
\text { 24th } \\
\text { 25th } \\
\text { 26th } \\
\text { 27th } \\
\text { or } \\
\text { Later }\end{array}$ & $\begin{array}{l}2 \\
1 \\
2 \\
2 \\
2 \\
2 \\
1 \\
1 \\
0 \\
0 \\
2 \\
0 \\
3 \\
3 \\
0 \\
1 \\
2 \\
1 \\
0 \\
0 \\
3 \\
0 \\
3 \\
0 \\
0 \\
2 \\
\\
5\end{array}$ & $\begin{array}{l}0 \\
0 \\
0 \\
0 \\
0 \\
1 \\
0 \\
0 \\
- \\
0 \\
0 \\
0 \\
1 \\
0 \\
0 \\
\frac{0}{1} \\
0 \\
\frac{0}{0} \\
0 \\
0\end{array}$ & $\begin{array}{l}0 \\
1 \\
1 \\
1 \\
0 \\
0 \\
0 \\
0 \\
\frac{1}{0} \\
\frac{1}{1} \\
\frac{1}{0} \\
0 \\
\frac{0}{7} \\
0 \\
0 \\
\frac{0}{0} \\
0\end{array}$ & $\begin{array}{l}0 \\
1 \\
0 \\
1 \\
0^{*} \\
0^{*} \\
1 \\
0 \\
-\overline{0} \\
0 \\
0 \\
1 \\
1 \\
0 \\
\frac{0}{0} \\
0 \\
0 \\
\frac{0}{0} \\
0 \\
0\end{array}$ \\
\hline \multicolumn{2}{|l|}{ Total } & 44 & 3 & 5 & 5 \\
\hline
\end{tabular}

* Birth weight not available for one child,
(5) Start of last menstrual period (mother's statement) mid-January, 1947, (calculated date) 23.1.47; onset of rubella 15.4.47; delivery 30.10.47. Birth weight $6 \mathrm{lb} .7 \mathrm{oz}$. $(2 \cdot 9 \mathrm{~kg}$.). Partial bilateral deafness, requiring education in a special school for deaf children. Deafness not detected at first examination (Hill and Galloway, Case 5). A test on the mother 4 years after the child's birth suggested that she might also have had a subclinical infection with toxoplasma.

(6) Start of last menstrual period (mother's statement) 31.1.52, (calculated date) 25.1.52; onset of rubella 5.5.52; delivery 1.11.52. Birth weight $5 \mathrm{lb} .6 \mathrm{oz}$. $(2 \cdot 4 \mathrm{~kg}$.). Mongol.

(7) Start of last menstrual period (mother's statement) 13.12.51, (calculated date) 29.12.51; onset of rubella 28.3.52; delivery 5.10.52. Stillbirth, weight $4 \mathrm{lb} .4 \mathrm{oz}$. $(1.9 \mathrm{~kg}$.). No specific cause found at autopsy. The mother also had an attack of herpes zoster during the pregnancy, starting on 17.3.52.

(8) Start of last menstrual period (calculated date) 5.2.46; onset of rubella 1.7.46; delivery 12.11.46. Birth weight not known. Died aged one week; certified cause pneumonia (Hill and Galloway, Case 8).

It will be seen that, of the seven infants whose mothers had rubella in the first 4 weeks of pregnancy, three had major and characteristic abnormalities. There were eleven cases of rubella occurring in the next 9 weeks, i.e. up to the end of the first trimester, and amongst these was one baby who died aged 5 weeks unexamined and one child who was deaf. As regards the first trimester, therefore, there were certainly four and possibly five affected babies in a total of eighteen. Of the fifteen infants whose mothers were infected in the second trimester, one was stillborn, one was a mongol, and one died at the age of one week, unexamined. A fourth child was found at the second examination, at the age of $4 \frac{1}{2}$ years, to have a moderately loud systolic murmur at the left sternal edge, varying in intensity with the position of the child; in the absence of any other signs, this has been regarded as physiological. The mother had had rubella in the 24th week of her pregnancy and the child's birth weight was $7 \mathrm{lb}$. $10 \mathrm{oz}$. $(3 \cdot 4 \mathrm{~kg}$.). Of the five infants whose mothers were infected in the third trimester, none showed any defect. This was also the case with the six infants whose mothers had had rubella before the last menstrual period.

Of the eight children known to be defective or who died before examination, the birth weight was available in six; four weighed $5 \mathrm{lb} .8 \mathrm{oz} .(2 \cdot 5 \mathrm{~kg}$.) or under, and none weighed as much as $7 \mathrm{lb}$. (3.2 kg.). 
Of the 36 normal children, 33 were known to be alive and well when aged 3 years or more; one was certified as having died at 5 months from "asphyxia due to overlaying" (maternal rubella one month before the last menstrual period, birth weight $8 \mathrm{lb} .(3.6 \mathrm{~kg}$.) ) and two were not traced after the initial examination. The birth weight was available in 35 ; one baby weighed $4 \mathrm{lb} .9 \mathrm{oz} .(1.8 \mathrm{~kg}$.), eight weighed over $5 \frac{1}{2}$ and less than $7 \mathrm{lb}$. ( $2 \cdot 5$ to $3 \cdot 2 \mathrm{~kg}$.), and 26 weighed $7 \mathrm{lb} .(3 \cdot 2 \mathrm{~kg}$.) or over.

Mumps.-The observations on mumps are set out in Table II and in the accompanying footnotes. One congenital defect (bilateral talipes equino-varus) was noted in the 29 instances in which the disease occurred during pregnancy. One child died of "white asphyxia" at the age of 3 days and the autopsy revealed no other specific defect. All the six infants whose mothers were infected before the last preceding menstrual period survived and no defects were observed.

Of the 33 normal children, 31 were known to be alive and well when aged 3 years or more, one had suffered from Still's disease and had died when aged $3 \frac{1}{2}$ years, and one was not traced after the initial examination. At birth, one of the normal children weighed $5 \mathrm{lb}$. $1 \mathrm{oz}$. $\left(2 \cdot 3 \mathrm{~kg}\right.$.), five weighed over $5 \frac{1}{2}$ and less than $7 \mathrm{lb}$. (2.5 to $3 \cdot 2 \mathrm{~kg}$.), and 26 weighed $7 \mathrm{lb}$. $(3 \cdot 2 \mathrm{~kg}$.) or more; the weight of one child was not known.

TABLE II

OBSERVATIONS ON MUMPS (EPIDEMIC PAROTITIS)

\begin{tabular}{|c|c|c|c|c|c|}
\hline \multicolumn{2}{|c|}{$\begin{array}{l}\text { Stage at which } \\
\text { Mumps } \\
\text { Commenced }\end{array}$} & \multirow{3}{*}{$\begin{array}{c}\begin{array}{c}\text { No. } \\
\text { of } \\
\text { Cases }\end{array} \\
\\
6\end{array}$} & \multirow{3}{*}{$\begin{array}{c}\begin{array}{c}\text { No. of } \\
\text { Babies } \\
\text { Stillborn } \\
\text { or who } \\
\text { Died } \\
\text { before } \\
\text { Examina- } \\
\text { tion }\end{array} \\
0\end{array}$} & \multirow{3}{*}{$\begin{array}{c}\text { No. of } \\
\text { Liveborn } \\
\text { Babies in } \\
\text { whom Ab- } \\
\text { normali- } \\
\text { ties were } \\
\text { Detected } \\
0\end{array}$} & \multirow{3}{*}{$\begin{array}{c}\begin{array}{c}\text { No. of } \\
\text { Babies } \\
\text { Born } \\
\text { weighing } \\
5 \frac{1}{2} \text { lb. or } \\
\text { Less }\end{array} \\
0\end{array}$} \\
\hline Before last & menstrual & & & & \\
\hline period & $\cdots \quad \cdots$ & & & & \\
\hline $\begin{array}{l}\text { Weeks of } \\
\text { Pregnancy }\end{array}$ & $\begin{array}{l}\text { 1st- 4th } \\
\text { 5th- 8th } \\
\text { 9th-12th } \\
\text { 13th-16th } \\
\text { 17th-20th } \\
\text { 21st-24th } \\
\text { 25th or } \\
\text { Later }\end{array}$ & $\begin{array}{r}1 \\
10 \\
5 \\
2 \\
1 \\
3 \\
7\end{array}$ & $\begin{array}{l}0 \\
0 \\
0 \\
1(b) \\
0 \\
0 \\
0\end{array}$ & $\begin{array}{l}\mathbf{0} \\
0 \\
1(a) \\
0 \\
0 \\
0 \\
0\end{array}$ & $\begin{array}{l}0 \\
0 \\
0 \\
0 \\
0 \\
1 \\
\\
0 *\end{array}$ \\
\hline Total & $\ldots$ & 35 & 1 & 1 & 1 \\
\hline
\end{tabular}

- Birthweight not available for one child.

(a) Start of last menstrual period (mother's statement and calculated date) 1.8.51; onset of mumps 2.10.51; delivery 8.5.52. Birth weight $7 \mathrm{lb}$. $12 \mathrm{oz}$. ( $3.5 \mathrm{~kg}$.). Bilateral talipes equino-varus.

(b) Start of last menstrual period (mother's statement) 21.7.50 (calculated date) 8.8.50; onset of mumps 21.10.50; delivery 15.5.51. Birth weight $6 \mathrm{lb}$. 11 oz. (3.0 kg.). Died on 3rd day with "white asphyxia"; no abnormalities detected at autopsy.
ChICKen Pox.-The observations on chicken pox are set out in Table III. The only congenital defect noted was an isolated defect of pancreatic secretion, and in this case the mother's infection had occurred 4 weeks before the start of the last menstrual period. Two babies were stillborn. Autopsy in one case showed atelectasis and suprarenal haemorrhage, with no specific congenital abnormality. The second foetus was 5 weeks premature and was macerated and a large clot was found behind the placenta. It may be recalled that another stillbirth followed an attack of herpes zoster in the 14th week of pregnancy, when the mother had also suffered from rubella in the 15 th week (Case 7).

Of the 28 normal children, 24 were known to be alive and well when aged 3 years or more, and four were not traced after the initial examination. Birthweights were available for 26 of the children; one weighed $5 \mathrm{lb} .6 \mathrm{oz}$. $\left(2.4 \mathrm{~kg}\right.$.), 12 weighed over $5 \frac{1}{2}$ and less than $7 \mathrm{lb}$. $(2.5$ and $3.2 \mathrm{~kg}$.) and 13 weighed $7 \mathrm{lb} .(3 \cdot 2 \mathrm{~kg}$.) or over.

TABLE III

OBSERVATIONS ON CHICKEN-POX (VARICELLA)

\begin{tabular}{|c|c|c|c|c|c|}
\hline \multicolumn{2}{|c|}{$\begin{array}{l}\text { Stage at which } \\
\text { Chicken-pox } \\
\text { Commenced }\end{array}$} & \multirow{2}{*}{$\begin{array}{c}\begin{array}{c}\text { No. } \\
\text { of } \\
\text { Cases }\end{array} \\
6\end{array}$} & \multirow{2}{*}{ 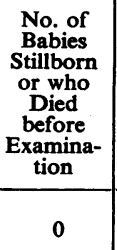 } & \multirow{2}{*}{$\begin{array}{c}\text { No. of } \\
\text { Liveborn } \\
\text { Babies in } \\
\text { whom Ab- } \\
\text { normali- } \\
\text { ties were } \\
\text { Detected } \\
1(a)\end{array}$} & \multirow{2}{*}{$\begin{array}{c}\begin{array}{c}\text { No. of } \\
\text { Babies } \\
\text { Born } \\
\text { weighing } \\
5 \frac{1}{2} \text { lb. or } \\
\text { Less }\end{array} \\
0\end{array}$} \\
\hline $\begin{array}{l}\text { Before last } \\
\text { period }\end{array}$ & $\begin{array}{c}\text { menstrual } \\
\ldots \quad \ldots\end{array}$ & & & & \\
\hline $\begin{array}{l}\text { Weeks of } \\
\text { Pregnancy }\end{array}$ & $\begin{array}{r}\text { 1st- 4th } \\
5 \text { th- 8th } \\
\text { 9th-12th } \\
\text { 13th-16th } \\
17 \text { th-20th } \\
21 \mathrm{st}-24 \text { th } \\
\text { 25th or } \\
\text { Later }\end{array}$ & $\begin{array}{l}1 \\
3 \\
3 \\
5 \\
2 \\
3 \\
8\end{array}$ & $\begin{array}{l}0 \\
0 \\
1(b) \\
0 \\
1(c) \\
0 \\
0\end{array}$ & $\begin{array}{l}\mathbf{0} \\
\mathbf{0} \\
\mathbf{0} \\
\mathbf{0} \\
\mathbf{0} \\
\mathbf{0} \\
\\
\mathbf{0}\end{array}$ & $\begin{array}{l}0 \\
0^{*} \\
0 \\
0 \\
1 \\
0 \\
1\end{array}$ \\
\hline Total & $\cdots$ & $31 t$ & 2 & 1 & 2 \\
\hline
\end{tabular}

* Birthweight not available for two children.

t Including one pair of twins (chicken-pox in the 5th week); excluding one normal child whose mother had chicken-pox in the 17 th week following rubella in the 5th week, and one stillborn child whose mother had herpes zoster in the 14th week and rubella in the 15 th week (Rubella Case 7).

(a) Start of last menstrual period (mother's statement and calculated date) 22.6.49; onset of chicken-pox 24.5.49; delivery 29.3.50. Birthweight 7 lb. 11 oz. $(3 \cdot 5 \mathrm{~kg}$.). Isolated defect of pancreatin secretion.

(b) Start of last menstrual period (mother's statement) 25.4.50, (calculated date) 29.4.50; onset of chicken-pox 10.7.50; delivery 3.2.51. Birthweight $9 \mathrm{lb} .3 \mathrm{oz}$. $(4 \cdot 2 \mathrm{~kg}$.). Stillborn; atelectasis and suprarenal haemorrhage found at autopsy; no other abnormality.

(c) Start of last menstrual period (mother's statement) 15.11.51, (calculated date) 12.10.51; onset of chicken-pox 24.3.52; delivery 19.7.52. Birthweight $4 \mathrm{lb}$. 6 oz. $(2 \cdot 0 \mathrm{~kg}$.). Stillborn; macerated foetus with large clot behind the placenta.

MeAsLes.-As nearly all children in Great Britain have measles, an attack is relatively rare in adult life, and Table IV gives data for only ten cases. In 
four of these, the attack of measles began before the menstrual period which preceded the pregnancy. Two congenital defects were observed-a right talipes equino-varus following measles that occurred one day before the start of the last menstrual period, and a cerebral diplegia following measles in about the 25th week of pregnancy. In the latter case, the mother had also shown signs of toxaemia one month before delivery. Of the eight normal children, six were known to be alive and well when aged 3 years or more, and two were not traced after the initial examination. Birthweights were available for six of the children; one weighed $4 \mathrm{lb} .5 \mathrm{oz} .(2 \cdot 0 \mathrm{~kg}$.) and the others all weighed $7 \mathrm{lb}$. $(3 \cdot 2 \mathrm{~kg}$.) or over.

TABLE IV

OBSERVATIONS ON MEASLES (MORBILLI)

\begin{tabular}{|c|c|c|c|c|c|}
\hline \multicolumn{2}{|c|}{$\begin{array}{l}\text { Stage at which } \\
\text { Measles } \\
\text { Commenced }\end{array}$} & \multirow{2}{*}{$\begin{array}{c}\begin{array}{c}\text { No. } \\
\text { of } \\
\text { Cases }\end{array} \\
4\end{array}$} & \multirow{2}{*}{$\begin{array}{c}\begin{array}{c}\text { No. of } \\
\text { Babies } \\
\text { Stillborn } \\
\text { or who } \\
\text { Died } \\
\text { before } \\
\text { Examina- } \\
\text { tion }\end{array} \\
0\end{array}$} & \multirow{2}{*}{$\begin{array}{c}\begin{array}{c}\text { No. of } \\
\text { Liveborn } \\
\text { Babies in } \\
\text { whom Ab- } \\
\text { normali- } \\
\text { ties were } \\
\text { Detected }\end{array} \\
1(a)\end{array}$} & \multirow{2}{*}{$\begin{array}{c}\begin{array}{c}\text { No. of } \\
\text { Babies } \\
\text { Born } \\
\text { weighing } \\
\text { 5t lb. or } \\
\text { Less }\end{array} \\
0\end{array}$} \\
\hline $\begin{array}{l}\text { Before last } \\
\text { period }\end{array}$ & $\begin{array}{c}\text { menstrual } \\
\ldots\end{array}$ & & & & \\
\hline $\begin{array}{l}\text { Weeks of } \\
\text { Pregnancy }\end{array}$ & $\begin{array}{c}\text { 1st- 4th } \\
\text { 5th- 8th } \\
\text { 9th-12th } \\
\text { 13th-16th } \\
\text { 17th-20th } \\
\text { 21st-24th } \\
\text { 25th or } \\
\text { Later }\end{array}$ & $\begin{array}{l}1 \\
0 \\
0 \\
1 \\
2 \\
0 \\
2\end{array}$ & $\begin{array}{l}\frac{0}{0} \\
\frac{0}{0} \\
0\end{array}$ & $\begin{array}{l}\frac{0}{-} \\
\frac{0}{0} \\
1(b)\end{array}$ & $\begin{array}{l}\frac{0}{\overline{0}} \\
0^{*} \\
0 \\
0 \\
0^{*}\end{array}$ \\
\hline Total & .. & 10 & 0 & 2 & 0 \\
\hline
\end{tabular}

* Birthweight not available for one child.

(a) Start of last menstrual period (mother's statement) 15.4.49, (calculated date) 26.4.49; onset of measles 14.4.49; delivery 31.1.50. Birthweight $6 \mathrm{lb}$. $3 \mathrm{oz}$. $(2 \cdot 8 \mathrm{~kg}$.). Right talipes equino-varus.

(b) Start of last menstrual period (calculated date) 28.9.46; onset of measles 27.3.47; delivery 5.7.47. Birthweight $7 \mathrm{lb}$. 9 oz. (3.4 kg.). Cerebral diplegia. The mother also had mild toxaemia one month before delivery.

\section{Discussion}

The present investigation is clearly not extensive enough to provide an accurate estimate of the risk of malformation following an attack of rubella at different stages during pregnancy. Reports have, however, been published of several other investigations in which a prospective method of inquiry has been strictly applied, and the results of these studies may be combined. The combined results of four such studies, reported by Brown and Nathan (1954), Brawner (1955), Pitt (1957), and the present authors, are shown in Table V. They comprise-with one exception-all the studies available to us which satisfy the following criteria:

(1) the occurrence of the attack of rubella was in every case recorded before the child was born;
(2) the children born to nearly all the affected mothers were subsequently examined;

(3) the data are published in sufficient detail for a separate estimate to be made of the risk for each month of pregnancy.

One other inquiry which satisfies these criteria was reported by Lamy and Seror (1956). Their results, however, are so different that it is preferable to consider them separately.

Table $\mathrm{V}$ shows that the risk of abnormality may be as high as 50 per cent. when the infection occurs in the first month of "pregnancy" (that is, in the 4 weeks following the start of the last preceding menstrual period). Subsequently, as the length of time between the last menstrual period and the appearance of the disease increases, the risk of abnormality steadily decreases. Of the nineteen mothers showing the disease in or after the 25th week, none gave birth to a defective child. Not all the defects included, however, can be attributed with certainty to the maternal disease. Of the eleven infants with major defects with whom the maternal disease had occurred within the first 2 months of pregnancy, all showed a congenital heart disease, cataract, or deafness. It may be presumed, therefore, that all these defects were the result of the infection. Of the three infants with defects whose mothers were reported to have been ill in the third month, two died of a congenital heart lesion and one had a hare lip and cleft palate. Of the three infants whose mothers were reported to have been ill in the fourth, fifth, and sixth months, one showed bilateral deafness (the mother's illness occurred in the 13th week of pregnancy), and the other two were respectively a mongol (maternal illness, 14th week) and an anencephalic (maternal illness, 21st week). It is possible that the last two defects were not related to the preceding rubella, and that therefore no defects were due to the maternal illness when it occurred after the 13th week of pregnancy (some fifty cases in all). On the other hand, a number of lesions attributable to the disease may have been omitted from the various inquiries represented in Table V. One foetus was stillborn and macerated following rubella in the 6th week, and another was stillborn, without any specific lesion being found at autopsy, following rubella in the 15th week. Two children died within 6 weeks of birth without being specially examined (following rubella in the 6th and 21st week), and one child was thought to have a "possible mild grade of pulmonary stenosis" following rubella in the 14th week (Pitt, 1957). Moreover, some of the children were examined on only one occasion and at a relatively early age 
(1 year or less) and cases of deafness may thus have been missed.

TABLE $\mathrm{V}$

RISK OF DEFECT IN THE INFANT FOLLOWING MATERNAL RUBELLA DURING PREGNANCY (Summation of data from four series)

\begin{tabular}{|c|c|c|c|c|}
\hline \multirow{2}{*}{\multicolumn{2}{|c|}{$\begin{array}{l}\text { Stage of Pregnancy } \\
\text { at which Rubella } \\
\text { Commenced }\end{array}$}} & \multirow{2}{*}{$\begin{array}{c}\text { Number } \\
\text { of } \\
\text { Cases }\end{array}$} & \multicolumn{2}{|c|}{ Infants with Major Defects } \\
\hline & & & Number & Per cent. \\
\hline $\begin{array}{l}\text { Weeks of } \\
\text { Pregnancy }\end{array}$ & $\begin{array}{c}\text { 1st- 4th } \\
\text { 5th- 8th } \\
\text { 9th-12th } \\
\text { 13th-16th } \\
\text { 17th-24th } \\
\text { 25th or } \\
\text { Later }\end{array}$ & $\begin{array}{l}12 \\
20 \\
18 \\
18 \\
17 \\
19\end{array}$ & $\begin{array}{l}6 \\
5 \\
3 \\
2 \\
1 \\
0\end{array}$ & $\begin{array}{r}50 \\
25 \\
17 \\
11 \\
6 \\
0\end{array}$ \\
\hline Total $\ldots$ & $\ldots$ & $104 *$ & 17 & - \\
\hline
\end{tabular}

- Excluding two cases which terminated in abortion (rubella in the Sth and 12th weeks respectively) and three cases in which the children could not be traced. One pair of fraternal twins (rubella in the 21 st week) is included as two cases.

The results of the inquiry of Lamy and Seror (1956), which were excluded from Table V, are summarized in Table VI. In this study, a questionnaire was sent to over 100,000 insured women who stated they were pregnant between 1.3.53 and 31.3.54. The questionnaires were sent out in the fifth month of the pregnancies. Nearly half the women replied: fifty stated that they had had rubella in the first 4 months of the pregnancy and 48 of these could be followed up. The results suggest that the risk to the foetus may be substantially greater than was observed in the four studies summarized in Table V.

TABLE VI

OBSERVATIONS OF LAMY AND SEROR (1956) ON EFFECTS OF MATERNAL RUBELLA DURING PREGNANCY

\begin{tabular}{|c|c|c|c|c|c|}
\hline & & & & $\underset{\text { Majo }}{\text { Infa }}$ & $\begin{array}{l}\text { Ints with } \\
\text { or Defects }\end{array}$ \\
\hline Rubella & $\begin{array}{l}\text { hich } \\
\text { ommenced }\end{array}$ & $\begin{array}{l}\text { of } \\
\text { Cases }\end{array}$ & $\begin{array}{l}\text { ending } \\
\text { in }\end{array}$ & & $\begin{array}{c}\text { No. as } \\
\text { per cent. }\end{array}$ \\
\hline $\begin{array}{l}\text { Weeks of } \\
\text { Pregmancy }\end{array}$ & $\begin{array}{l}\text { 1st-4th } \\
5 \text { th- 8th } \\
9 \text { th-12th } \\
\text { 13th-20th }\end{array}$ & $\begin{array}{r}7 \\
21 \\
12 \\
8\end{array}$ & $\begin{array}{l}0 \\
5 \\
0 \\
1\end{array}$ & $\begin{array}{r}6 \\
13 \\
3 \\
3\end{array}$ & $\begin{array}{l}86 \\
81 \\
25 \\
43\end{array}$ \\
\hline Total & $\ldots$ & 48 & 6 & $25 *$ & - \\
\hline
\end{tabular}

* One other child was stillborn (rubella in the 8th week) and one died at the age of 15 days, cause unknown (rubella in the 11 th week).

Other studies, however, have suggested that the risk may be lower. Greenberg, Pelliteri, and Barton (1957), for example, have summarized the data from seven series not included in Table V. Among .96 infants born to mothers affected by rubella during the first trimester of pregnancy, six were stillborn (6.3 per cent.) and only seven showed any major congenital defect $(7 \cdot 3$ per cent.). In most of the series it is not possible to distinguish between the risks in the various months of the first trimester, and, since rubella in the early months has been regarded as an indication for abortion, it is possible that the data are disproportionately weighted with cases occurring towards the end of that trimester. This, however, cannot account for the low incidence of defects reported by Lundström (1952). An epidemic of rubella occurred in Sweden in the spring of 1951 and the staffs of all the Swedish maternity hospitals were requested to question all women who were delivered in them or who were treated for a spontaneous abortion during the following year. Altogether 1,067 women reported that they had had rubella during pregnancy. The proportion of stillbirths, neonatal deaths, and congenital abnormalities rose from 10 per cent. when the disease was contracted in the first month, to 14 per cent. for the second month; it fell again to 10 per cent. for the third month and finally to about 3 per cent. for the last 4 months of pregnancy. The corresponding figure for a control group of 2,452 children born in the same hospital at the same period was approximately 4 per cent.

The great differences in the results obtained by different groups of workers may be explained, in part, by the operations of chance and, in part, by differences in the methods used to investigate the problems and in the presentation of the results. It seems unlikely, however, that all the differences can be thus explained, and it is possible that the effect of a maternal attack of rubella may vary in space and time.

The results obtained in the present study from the follow-up of mothers who were infected during their pregnancy with mumps, chicken pox, or measles, provide no clear evidence of any deleterious effect of these diseases on the foetus. The only possible exception was chicken pox. Half the mothers who suffered from this disease gave birth to children weighing less than $7 \mathrm{lb}$., compared with 22 per cent. of the normal infants born to mothers who had one of the other diseases. The mean birth weights were not,

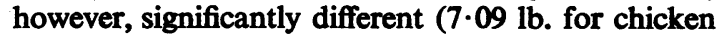
pox and 7.43 for the other diseases: " $t$ " $=1.48$; $P$ greater than $0 \cdot 1$ ). Other workers (for example, Grönvall and Selander, 1948) failed to observe any characteristic effect from these infections and it seems very unlikely that they carry any important risk to the foetus. 


\section{SUMMARY}

By a special recording system the occurrence of certain infectious diseases was noted in women whose illness, medically observed and diagnosed, fell during, or shortly before, a pregnancy. Information was subsequently sought regarding the infants born to them (live or still but excluding abortions or miscarriages), shortly after birth and again at an age of not less than 3 years. Data were thus acquired on 44 cases of German measles (rubella), 35 of mumps (epidemic parotitis), 30 of chicken pox (varicella), and 10 of measles (morbilli). There was no evidence that mumps or measles had had any deleterious effect upon the foetus. With chicken pox there was also no evidence of the production of congenital defects, but the proportion of liveborn children with low birth weights was relatively high (though the difference was not statistically significant). With rubella occurring early in pregnancy, the well-known congenital defects of heart, vision, and hearing were observed.

By the addition of these present cases to similar published records, some estimates are reached of the risks involved with rubella in different stages of pregnancy. An incidence of six affected children out of twelve with rubella in the mother in the first month of pregnancy (50 per cent.) declines to five out of twenty for the second month ( 25 per cent.) and to three out of eighteen for the third month (17 per cent.). With 54 women in whom the attack of rubella occurred in the second and third trimesters, 51 infants were unaffected, and only one of the three affected cases seemed likely to be attributable to the preceding rubella.

Other published data have shown both considerably higher and considerably lower incidence rates of congenital defects following rubella in early pregnancy. It may be therefore that the risk varies in space or time.

We are indebted to the Ministry of Pensions and National Insurance for putting in operation the system by which we were notified of the majority of the cases, and in particular to Sir Arthur Massey, the Chief Medical Officer, for much help and advice; we are also indebted to the doctors who notified us of the seven cases which were brought to our attention privately, to Dr. R. Burtles who, while working in the Statistical Research Unit, carried out the second examination on a number of the children, to the practitioners and specialists who examined some cases on our behalf, and to Miss Keena Jones, of the Statistical Research Unit, who traced the whereabouts of many of the children and who interviewed some of the elder children and their mothers.

\section{REFERENCES}

Biawner, D. L. (1955), J. med Ass. Ga, 44,451.

Brown, C. M., and Nathan, B. J. (1954). Lancet, 1, 975.

Greenberg, M., Pellitteri, O., and Barton, J. (1957). J. Amer. med.

Ass., $165,675$.
Grönvall, H., and Selander, P. (1948). Nord. Med., 37, 409.

Hill, A. Bradford, and Galloway, T. M. (1949). Lancet, 1, 299

Lamy, M., and Seror, M. E. (1956). Sem. méd. prof. méd.-soc., 32, 1085.

Lundström, R. (1952). Acta paediat. (Uppsala), 41, 583.

Pitt, D. B. (1957). Med. J. Austr., 1, 233. 